\title{
SYNTHESIS, CHARACTERIZATION, AND CYTOTOXICITY OF BINUCLEAR COPPER(II)-COMPLEXES WITH SOME S-ALKENYL DERIVATIVES OF THIOSALICYLIC ACID
}

Dusan Lj. Tomovic ${ }^{1}$, Andriana M. Bukonjic ${ }^{1}$, Aleksandar Kocovic ${ }^{1}$, Milos V. Nikolic ${ }^{1}$, Marina Z. Mijajlovic ${ }^{1}$, Verica V. Jevtic ${ }^{2}$, Zoran R. Ratkovic ${ }^{2}$, Aleksandar N. Arsenijevic ${ }^{1}$, Jelena Z. Milovanovic ${ }^{1}$, Bojana Stojanovic ${ }^{1}$, Srecko R. Trifunovic ${ }^{2}$, Gordana P. Radic ${ }^{1}$ ${ }^{1}$ Faculty of Medical Sciences, University of Kragujevac, ${ }^{2}$ Department of Chemistry, Faculty of Science, University of Kragujevac ${ }^{3}$ Center for Molecular Medicine and Stem Cell Research, Faculty of Medical Sciences, University of Kragujevac SINTEZA, KARAKTERIZACIJA I CITOTOKSIČNOST BINUKLEARNIH BAKAR(II)-IKOMPLEKSA

SA NEKIM S-ALKENIL DERIVATIMA TIOSALICILNE KISELINE

Dušan Lj. Tomović ${ }^{1}$, Andriana M. Bukonjić ${ }^{1}$, Aleksandar Kočović ${ }^{1}$, Miloš V. Nikolić ${ }^{1}$, Marina Ž. Mijajlović ${ }^{1}$, Verica V. Jevtić ${ }^{2}$, Zoran R. Ratković ${ }^{2}$,

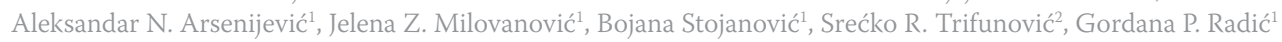
${ }^{1}$ Fakultet medicinskih nauka, Univerzitet u Kragujevcu

${ }^{2}$ Institut za hemiju, Prirodno-matematički fakultet, Univerzitet u Kragujevcu

${ }^{3}$ Centar za molekulsku medicine i istraživanje matičnih ćelija, Fakultet medicinskih nauka, Univerzitet u Kragujevcu

Received / Primljen: 12. 07. 2016.

Accepted / Prihvaćen: 25. 07. 2016.

\begin{abstract}
New complexes of copper(II) with S-alkenyl derivatives of thiosalicylic acid (alkenyl = propenyl-(L1), isobutenyl-(L2)) have been synthesized and characterized by microanalysis, infrared spectra, magnetic measurements, and by NMR spectra. The cytotoxic activity of two newly synthesized precursor S-alkenyl derivatives of thiosalicylic acid were tested using an MTT colorimetric technique on HCT-116 human colon carcinoma cells. The cytotoxic effect of the copper(II)complexes were higher compared to the cytotoxicity of the corresponding ligand (for concentrations from 31.25 to 250 $\mu M)$. Copper(II)-complexes showed a slightly lower cytotoxicity compared to cisplatin. Complexes of copper(II) with S-alkenyl derivatives of thiosalicylic acid (at concentrations from 250 to $1000 \mu \mathrm{M}$ ) had a cytotoxic effect on HCT-116 cells compared to cisplatin.
\end{abstract}

Keywords: S-alkenyl derivatives of thiosalicylic acid, copper(II)-complexes, IR and NMR spectroscopy, cytotoxic activity

\section{SAŽETAK}

Novi bakar(II)-kompleksi sa nekim S-alkenil derivatima tiosalicilne kiseline (alkenil = propenil-(L1), izobutenil-(L2)) su sintetisani i okarakterisani na osnovu rezultata mikroanalize, infracrvenih spektara i magnetnih merenja, dok su odgovarajući S-alkenil derivati okarakterisani i na osnovu NMR spektara. Citotoksična aktivnost dva novosintetisana liganda S-alkenil derivata tiosalicilne kiseline je ispitivana pomoću MTT kolorimetrijske tehnike na humanim ćelijama karcinoma debelog creva, HCT-116. Citotoksični efekat bakar(II)-kompleksa je bio veći u poređenju sa citotoksičnošću odgovarajućih liganada (u koncentracijama od 31,25 do $250 \mu \mathrm{M}$ ). Bakar(II)-kompleksi su pokazali neznatno nižu citotoksičnost u poređenju sa cisplatinom. Bakar(II)-kompleksi sa S-alkenil derivatima tiosalicilne kiseline (u koncentracijama od 250 do $1000 \mu \mathrm{M}$ ) imali su citotoksični efekat na HCT-116 ćelijama kao cisplatina.

Ključne reči: S-alkenil derivati tiosalicilne kiseline, bakar(II)-kompleksi, IR i NMR spektroskopija, citoksična aktivnost

\section{ABBREVIATIONS}

MTT - 3-(4,5-dimethylthiazol-2-yl)-2,5-diphenyl tetrazolium bromide

IR - infrared

NMR - nuclear magnetic resonance

$\mathrm{Cu}$ - copper

Zn - zinc

VD - Wilson's disease

MD - Menkes disease
ROS - reactive oxygen species

$\mathrm{Cu}\left(\mathrm{NO}_{3}\right)_{2}$ - copper(II)-nitrate trihydrate

LiOH - lithium hydroxide

DMSO - dimethyl sulfoxide

DMEM - Dulbecco's Modified Eagle Medium

FBS - fetal bovine serum

EDTA - ethylenediaminetetraacetic acid

PBS - phosphatebuffered saline

BM - bending magnet 


\section{INTRODUCTION}

After successful application of "cisplatin" (cisdiamminedichloroplatinum(II)) to chemotherapy in cancer patients, the exploration of other metal-complexes as new anticancer agents has continued, to enhance their specificity towards cancer cells, reduce toxic side effects, and prevent the development of resistance in human cancer cells (1-5).

Copper is an essential element for all organisms who live in environments rich in oxygen. This redox active metal converts oxidation state easily from a $\mathrm{Cu}(\mathrm{I})$ to $\mathrm{Cu}(\mathrm{II})$, and vice versa, as in chemical reactions and in physiological conditions (6). Copper is essential for the function of several enzymes and proteins, such as cytochrome oxidase, $\mathrm{Zn}, \mathrm{Cu}$-superoxide dismutase, lysyl oxidase, tyrosinase, and dopamine-b-monooxygenase $(1,6,7)$.

The importance of copper is also reflected in the fact that its deficiency leads to congenital genetic diseases, such as Wilson's disease (VD) and Menkes disease (MD) (8). Copper chelation therapy has attracted considerable attention for use in research and treatment of various neurodegenerative disorders (9).

The presence of proteins found in copper has been associated to metabolic changes in cancer cells. The exact role of copper in the treatment of cancer has not been sufficiently clarified $(6,10)$. It is assumed that copper is involved in the generation of ROS (reactive oxygen species) and the process of angiogenesis by stimulating the proliferation and migration of human endothelial cells (10-12).

Thiosalicylic acid and its derivatives have a wide range of applications. It has been used for the determination of metals $(13,14)$; as modifiers of graphite paste electrodes (15); as photoinitiators of free radical polymerization (16); in cosmetics (17); in the treatment of dermatological (18), inflammatory, allergic, and respiratory diseases (19); and as Ras-tumour growth inhibitors (20).

Copper(II)-complexes may exert cytotoxic activity on colon carcinoma cell lines. O'Halloran found that a copper complex $\left(\mathrm{Cu}[\mathrm{N}\right.$-salicylidene-(glutamate $\left.\left.)\left(\mathrm{H}_{2} \mathrm{O}\right)_{2}\right] \cdot \mathrm{H}_{2} \mathrm{O}\right)$ at concentrations of 50 and $100 \mu \mathrm{mol} / \mathrm{L}$ was shown to have distinct cytotoxic activity in human HT-29 colon cancer cells after 72 hours. Apoptosis was activated by the generation of large quantities of free radicals (21).

Various studies have confirmed the synthesis and structural characterization of different complexes of copper(II) with thiosalicylic acid as a ligand $(22,23)$. Complexes of copper(II) with the S-alkyl derivatives of thiosalicylic acid showed moderate antimicrobial activity and low antifungal activity (24). With consideration for these effects, new research examining the cytotoxic potential of copper(II) with S-alkyl derivatives of thiosalicylic acid has found that these derivatives exhibit a lower cytotoxicity compared to cisplatin in the human HCT-116 cell line and in murine cell lines CT26 and CT26.CL25 (25).
The first aim of our study was to synthesize two new ligands acting as S-alkenyl derivatives of thiosalicylic acid (alkenyl = propenyl-(L1), isobutenyl-(L2)), and two corresponding copper(II)-complexes with these ligands. The composition and structure of S-alkenyl derivatives of thiosalicylic acid was assumed on the basis of microanalysis, IR, and NMR spectroscopy. The composition and structure of synthesized complexes was confirmed based on the microanalysis, IR spectroscopy, and magnetic measurements. Another aim of our study was to investigate the cytotoxic potential of copper(II)-complexes with S-alkenyl derivatives of thiosalicylic acid on the human colon cancer cell line HCT-116.

\section{MATERIALS AND METHODS}

\section{Materials and measurements}

The reagents were obtained commercially and used without further purification. Elemental analyses were conducted on a Vario III CHNOS Elemental Analyser, Elemental Analysensysteme GmbH. For infrared spectra, a Perkin-Elmer FTIR 31725-X spectrophotometer, and KBr pellet technique were employed.

\section{Syntheses}

General procedure for the synthesis of S-alkenyl derivatives of thiosalicylic acid

The S-alkenyl derivatives of the thiosalicylic acid ligand (alkenyl = propenyl-(L1), isobutenyl-(L2)) were prepared (26) by alkylation of thiosalicylic acid using the corresponding alkenyl halides in alkaline water-ethanol solution.

S-propenyl derivative of thiosalicylic acid (S-propenylthiosal), (L1): M.p. $180-181^{\circ} \mathrm{C}$, white powder, IR ( $\mathrm{KBr}, \mathrm{cm}$ $\left.{ }^{1}\right)$ : 3446, 3075, 2917, 2654, 2557, 1680, 1586, 1562, 1465, $1415,1314,1273,1256,1153,1061,1045,889,741,701$, 651, and 551. ${ }^{1} \mathrm{H}$ NMR $\left(200 \mathrm{MHz}, \mathrm{CDCl}_{3}, \delta \mathrm{ppm}\right): 3.21(\mathrm{~d}$, $\left.2 \mathrm{H}, \mathrm{CH}_{2}\right), 5.92(\mathrm{~m}, 1 \mathrm{H}, \mathrm{CH}), 4.93\left(\mathrm{~m}, 2 \mathrm{H}, \mathrm{CH}_{2}\right)$ and $7.47-$ $7.91(\mathrm{~m}, 4 \mathrm{H}, \mathrm{Ar}) .{ }^{13} \mathrm{C}$ NMR $\left(50 \mathrm{MHz}, \mathrm{CDCl}_{3}, \delta \mathrm{ppm}\right): 38.2$ $\left(\mathrm{CH}_{3}\right), 115.9\left(\mathrm{CH}_{2}\right), 136.5(\mathrm{CH}), 125.3 ; 125.6 ; 130.2 ; 131.7$; 133.8; $140.1(\mathrm{Ar})$, and $172.0(\mathrm{COOH})$.

$\mathrm{S}$-isobutenyl derivative of thiosalicylic acid (S-isobutenyl-thiosal), (L2): M.p. $182-183^{\circ} \mathrm{C}$, white powder, IR (KBr, $\left.\mathrm{cm}^{-1}\right): 3445,3076,2967,2647,2556,1676,1585,1562,1463$, $1412,1317,1272,1253,1154,1061,1046,810,743,651$, and 550. ${ }^{1} \mathrm{H}$ NMR $\left(200 \mathrm{MHz}, \mathrm{CDCl}_{3}, \delta \mathrm{ppm}\right): 1.82\left(\mathrm{~s}, 3 \mathrm{H}, \mathrm{CH}_{3}\right)$, $4.98\left(\mathrm{~m}, 2 \mathrm{H}, \mathrm{CH}_{2}\right), 3.44\left(\mathrm{t}, 2 \mathrm{H}, \mathrm{CH}_{2}\right)$, and $7.42-8.30(\mathrm{~m}, 4 \mathrm{H}$, Ar). ${ }^{13} \mathrm{C}$ NMR (50 MHz, $\left.\mathrm{CDCl}_{3}, \delta \mathrm{ppm}\right): 22.5\left(\mathrm{CH}_{3}\right), 46.1$ $\left(\mathrm{CH}_{2}\right), 112.1\left(\mathrm{CH}_{2}\right), 125 ; 126.5 ; 126.7 ; 133.2 ; 134.1 ; 142.6$ $(\mathrm{Ar})$, and $168.1(\mathrm{COOH})$.

Preparation of copper(II)-complex with S-propenyl derivative of thiosalicylic acid $\left[\mathrm{Cu}_{2}(\mathrm{~S}\right.$-propenylthiosal $\left.)_{4}\left(\mathrm{H}_{2} \mathrm{O}\right)_{2}\right](\mathrm{Cl})$

Copper(II)-nitrate trihydrate $(0.1000 \mathrm{~g}, 0.4139 \mathrm{mmol})$ was dissolved in $10.0 \mathrm{~mL}$ of water on a steam bath, and S-propenyl derivative of thiosalicylate $(0.1607 \mathrm{~g}, 0.8278$ 
mmol) was subsequently added. The reaction mixture was heated for $3 \mathrm{~h}$, and during this period $10.0 \mathrm{ml}$ of $\mathrm{LiOH}$ water solution $(0.0199 \mathrm{~g}, 0.8278 \mathrm{mmol})$ was added in small portions. The solution was filtered and evaporated to a small volume. The blue precipitate of copper(II)-complex was separated by filtration, washed with cold water, and air-dried. Yield: 0.1604 g (81.5\%). Anal. Calc. for $\left.\left[\mathrm{Cu}_{2} \text { (S-propenyl-thiosal }\right)_{4}\left(\mathrm{H}_{2} \mathrm{O}\right)_{2}\right]=\mathrm{Cu}_{2} \mathrm{C}_{41} \mathrm{H}_{43} \mathrm{O}_{10} \mathrm{~S}_{4}(\mathrm{Mr}=$ 951.126): C, 51.77; H, 4.56; and S, 13.49. Found: C, 51.54; $\mathrm{H}, 4.42$; and $\mathrm{S}, 13.29 . \mu(294 \mathrm{~K})=1.84 \mu_{\mathrm{B}}$.

IR $\left(\mathrm{KBr}, \mathrm{cm}^{-1}\right): 3441,3076,2918,1610,1549,1460$, $1435,1400,1281,1258,1229,1156,1062,1044,846,744$, 695,658 , and 556.

Preparation of copper(II)-complex with S-isobutenyl derivative of thiosalicylic acid $\left[\mathrm{Cu}_{2}(\mathrm{~S}\right.$-isobutenylthiosal $\left.{ }_{4}\left(\mathrm{H}_{2} \mathrm{O}\right)_{2}\right](\mathrm{C} 2)$

Copper(II)-nitrate trihydrate $(0.1000 \mathrm{~g}, 0.4139 \mathrm{mmol})$ was dissolved in $10.0 \mathrm{~mL}$ of water on a steam bath, and S-isobutenyl derivative of thiosalicylate $(0.1723 \mathrm{~g}, 0.8278 \mathrm{mmol})$ was subsequently added. The reaction mixture was heated for $3 \mathrm{~h}$, and during this period $10.0 \mathrm{~mL}$ of $\mathrm{LiOH}$ water solution $(0.0199 \mathrm{~g}$, $0.8278 \mathrm{mmol}$ ) was added in small portions. The solution was filtered and evaporated to a small volume. The blue precipitate of copper(II)-complex was separated by filtration, washed with cold water, and air-dried. Yield: $0.2228 \mathrm{~g}(82.1 \%)$. Anal. Calc. for $\left[\mathrm{Cu}_{2}(\mathrm{~S} \text {-isobutenyl-thiosal })_{4}\left(\mathrm{H}_{2} \mathrm{O}\right)_{2}\right]=\mathrm{Cu}_{2} \mathrm{C}_{45} \mathrm{H}_{51} \mathrm{O}_{10} \mathrm{~S}_{4}(\mathrm{Mr}=$ 1007.232): C, 53.66; H, 5.10; and S, 12.73. Found: C, 53.47; H, 5.18; and $S, 12.64 . \mu(294 \mathrm{~K})=1.86 \mu_{\mathrm{B}}$

IR $\left(\mathrm{KBr}, \mathrm{cm}^{-1}\right): 3446,2969,2915,1613,1589,1400$, $1281,1257,1157,1062,847,744,719,656$, and 510.

\section{Preparation of drug solutions}

Complexes were dissolved in $10 \%$ dimethylsulfoxide (DMSO) in distilled water at a concentration of $10 \mathrm{mM}$ and filtered through a $0.22 \mathrm{~mm}$ Millipore filter. These stock solutions were diluted in culture medium immediately before use. MTT, 3-(4,5-dimethylthiazol-2-yl)-2,5- -diphenyl tetrazolium bromide was dissolved $(5 \mathrm{mg} / \mathrm{mL})$ in a phosphate buffer saline having a $\mathrm{pH}$ of 7.2, and filtered through the $0.22 \mathrm{~mm}$ Millipore filter before use. All reagents were purchased from Sigma Chemicals.

\section{Cell culture}

HCT-116 cells were kindly provided by Dr Danijela Vignjević (Institute Curie, Paris, France). Cells were main- tained in DMEM (Sigma Aldrich, Munich, Germany) supplemented with $10 \%$ fetal bovine serum (FBS, Sigma Aldrich, Munich, Germany), penicillin (100 IU/mL), and streptomycin $(100 \mu \mathrm{g} / \mathrm{mL})$ in a humidified atmosphere of $95 \%$ air and $5 \% \mathrm{CO}_{2}$ at $37^{\circ} \mathrm{C}$. Subconfluent monolayers in the logarithmic growth phase were harvested by a brief treatment with $0.25 \%$ trypsin and $0.02 \%$ EDTA in phosphate-buffered saline (PBS, PAA Laboratories GmbH) and washed three times in serum-free PBS. The number of viable cells was determined by trypan blue exclusion.

\section{Cytotoxicity assays}

The effects of the tested compounds on cell viability were determined using the MTT colorimetric technique (27). HCT-116 cells were diluted with growth medium to $5 \cdot 10^{4}$ cells $/ \mathrm{mL}$, and aliquots $\left(5 \cdot 10^{3}\right.$ cells $\left./ 100 \mathrm{~mL}\right)$ were placed in individual wells in 96-well plates. The next day the medium was exchanged with $100 \mu \mathrm{L}$ of different compounds, which had been serially diluted 2 -fold in the medium to concentrations ranging from $1000 \mu \mathrm{M}$ to $7.8 \mu \mathrm{M}$ in growth medium. Each compound was tested in triplicate. Cells were incubated at $37^{\circ} \mathrm{C}$ in $5 \% \mathrm{CO}_{2}$ for $72 \mathrm{~h}$. After incubation the supernatant was removed, and 15\% MTT solution $(5 \mathrm{mg} / \mathrm{mL}$ in PBS, $10 \mu \mathrm{L}$ ) in DMEM without FBS was added to each well. After an additional $4 \mathrm{~h}$ of incubation at $37^{\circ} \mathrm{C}$ in $5 \% \mathrm{CO}_{2}$, the medium with MTT was removed and DMSO $(150 \mu \mathrm{L})$ with glycine buffer $(20 \mu \mathrm{L})$ was added to dissolve the crystals. The plates were shaken for $10 \mathrm{~min}$. The optical density of each well was determined at $595 \mathrm{~nm}$ using microplate Zenyth 3100 Multimode detector. The percentage of cytotoxicity was calculated using the formula: \% cytotoxicity $=100-((E-B) /(S-B) \cdot 100)$, where $B$ is the background of medium alone, $S$ is total viability/ spontaneous death of untreated target cells, and $\mathrm{E}$ is experimental well. Each of the tested complexes was evaluated for cytotoxicity in three separate experiments.

\section{RESULTS AND DISCUSSION}

\section{Synthesis and chemical characterization}

S-alkenyl ( $\mathrm{R}$ = propenyl-(L1), isobutenyl-(L2)) derivatives of thiosalicylic acid were prepared (26) by alkylation of thiosalicylic acid using the corresponding alkenyl halogenides in an alkaline water-ethanol solution (Scheme 1). The corresponding complexes were obtained by a direct<smiles>[R]Sc1ccccc1C(=O)O</smiles>

Scheme 1. Synthesis method of S-alkenyl derivates of thiosalicylic acid, R = propenyl-(L1), isobutenyl-(L2). 


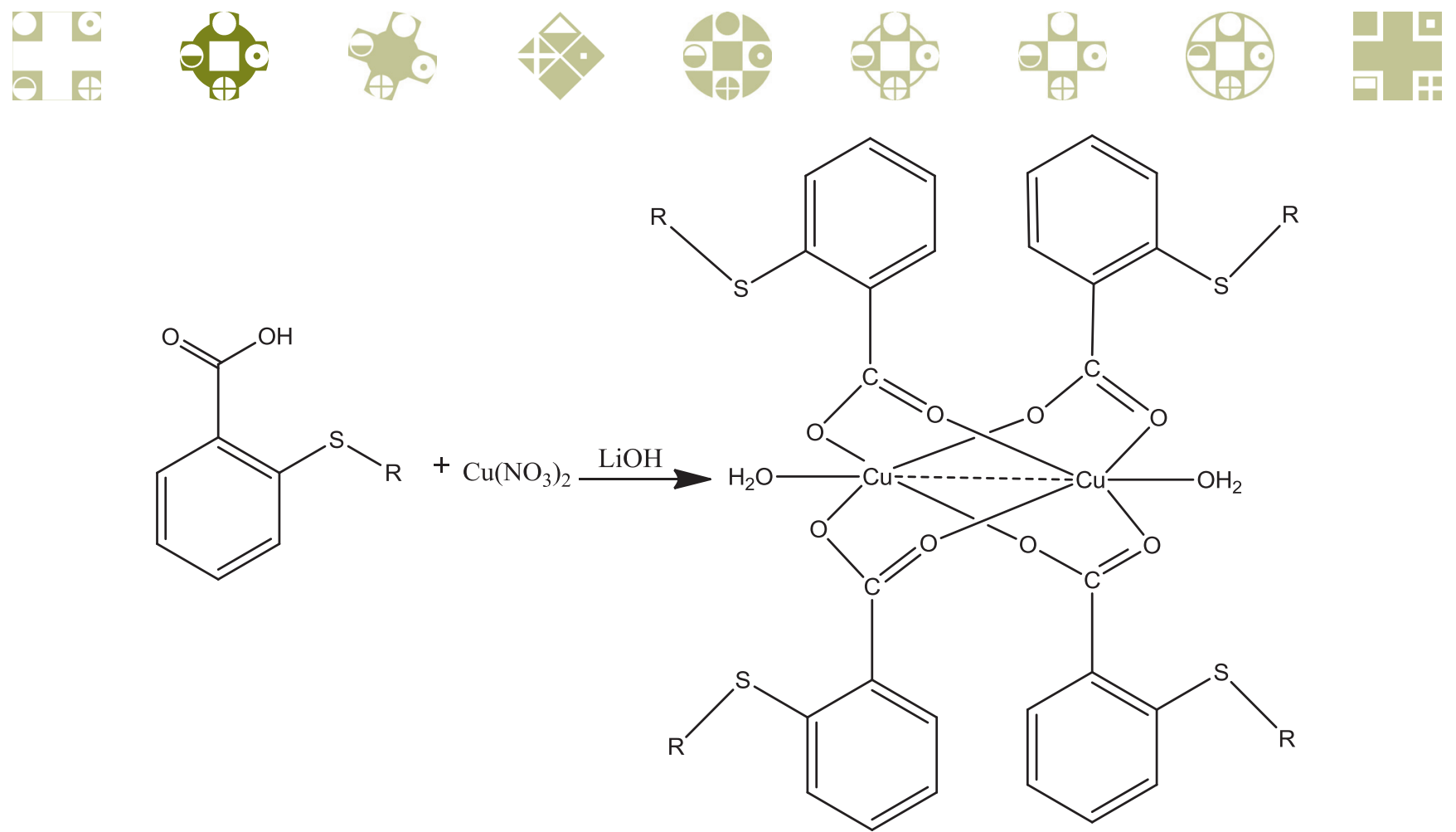

Scheme 2. Synthesis of copper(II)-complex with S-alkenyl derivates of thiosalicylic acid, R = propenyl-(C1), isobutenyl-(C2).

Table 1. The most important infrared bands $\left(\mathrm{cm}^{-1}\right)$ of the investigated compounds.

\begin{tabular}{|c|c|c|c|}
\hline Compound & $-\mathbf{S}-\mathbf{R}$ & $-\mathrm{COO}^{-}$(as) & $-\mathrm{COO}^{-}(\operatorname{sim})$ \\
\hline S-propenyl-thiosal (L1) & $702(\mathrm{~m})$ & $1680(\mathrm{~s})$ & $1415(\mathrm{~s})$ \\
\hline $\begin{array}{l}{\left[\mathrm{Cu}_{2}(\mathrm{~S} \text {-propenyl- }\right.} \\
\left.\text { thiosal })_{4}\left(\mathrm{H}_{2} \mathrm{O}\right)_{2}\right](\mathbf{C 1})\end{array}$ & $696(\mathrm{~m})$ & $\begin{array}{l}1610(\mathrm{~s}) \\
1596(\mathrm{~s})\end{array}$ & $1401(\mathrm{~s})$ \\
\hline S-isobutenyl-thiosal (L2) & $702(\mathrm{~m})$ & $1676(\mathrm{~s})$ & $1412(\mathrm{~s})$ \\
\hline $\begin{array}{l}{\left[\mathrm{Cu}_{2}(\mathrm{~S} \text {-isobutenyl- }\right.} \\
\left.\text { thiosal })_{4}\left(\mathrm{H}_{2} \mathrm{O}\right)_{2}\right](\mathbf{C 2})\end{array}$ & $697(\mathrm{~m})$ & $\begin{array}{l}1613(\mathrm{~s}) \\
1589(\mathrm{~s})\end{array}$ & $1400(\mathrm{~s})$ \\
\hline
\end{tabular}

s-strong, m-medium

reaction of copper(II)-nitrate trihydrate with S-alkenyl derivatives of thiosalicylic acid (molar ratio 1:2) in a water solution with satisfactory yields (more than $80 \%$ ) (Scheme 2).

Infrared spectra of the isolated complexes were measured to find the coordination mode of the S-alkenyl derivatives of thiosalicylic acid. The asymmetric stretching frequencies of the carboxyl group were used to determine whether it was coordinated (the absorption bands are located in the region $1600-1650 \mathrm{~cm}^{-1}$ ) or uncoordinated (the absorption bands are located in the region 1700-1750 cm $\left.{ }^{1}\right)$ to the metal ion $(28-30)$. The infrared spectra of complexes $\mathrm{C} 1$ and $\mathrm{C} 2$ indicated that the carboxyl groups of S-alkenyl derivatives of thiosalicylic were definitely coordinated to the central copper(II)-complexes.

The isolated $\left(\mathrm{Cu}_{2}(\mathrm{~S} \text {-alkenyl-thiosal })_{4}\left(\mathrm{H}_{2} \mathrm{O}\right)_{2}\right]$ complexes show double sharp and strong asymmetric stretching frequencies of the carboxyl groups of the coordinated Salkenyl derivatives of thiosalicylic acid to $\mathrm{Cu}(\mathrm{II})$-ion at approximately $1548-1615 \mathrm{~cm}^{-1}$ (Table 1 ). The observed clear double bands for isolated complexes suggest small differences in the coordination of the carboxyl groups of the ligands to the copper(II)-ion. Based on previously published results from structurally similar ligands, we can conclude that there was a coordination of S-alkenyl derivatives of thiosalicylic acid with copper(II)-ions in forming binuclear complexes.

Additionally, the strong sharp single symmetric stretching bands of the coordinated carboxyl groups of the S-alkenyl derivatives of thiosalicylic acid lie in the expected region (approximately $1400 \mathrm{~cm}^{-1}$ ).

\section{Magnetic measurements}

Binuclear copper(II)-complexes $(31,32)$ are stable in dimeric form. The low value of $\mu_{\text {eff }}$ at room temperature (approximately $1.86 \mathrm{BM}$ ) is indicative of an antiferromagnetic interaction between the two metal centres typical of binuclear carboxylates of copper(II) of the type: $[\mathrm{Cu}(\mathrm{R}$ $\left.\mathrm{COO})_{2} \mathrm{~L}\right]_{2}(33-35)$. The main factor determining the magnitude of the antiferromagnetic interaction in the dimeric copper(II) carboxylates is the electronic structure of the bridging OCO moiety, as published previously (31, 32-35).

\section{Anticancer activity of copper(II)-complexes}

The MTT assay for cell viability shows that the two newly synthesized precursor S-alkenyl derivatives of thiosalicylic acid, as well as their corresponding copper(II)complexes, exhibit cytotoxic activity in HCT-116 human colon carcinoma cells after 24 hours (Figure 1). The cytotoxic effect of the copper(II)-complexes was higher than the cytotoxicity of the corresponding ligands, especially for concentrations from 31.25 to $250 \mu \mathrm{M}$. Copper complexes showed slightly lower cytotoxicity compared to cisplatin. However, higher concentrations of C2 (250-1000 $\mu \mathrm{M})$ had an almost equal cytotoxic effect on HCT-116 cells, relative to cisplatin. 


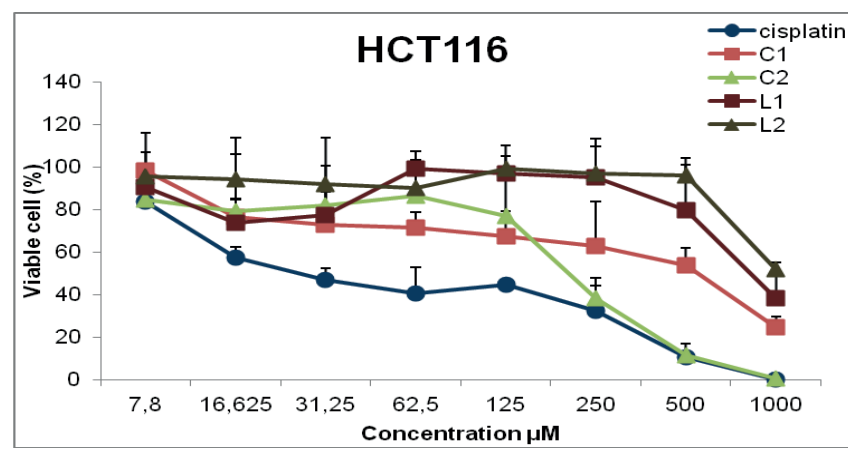

Figure 1. Representative graphs of HCT-116 cell survival after 24 h cell growth in the presence of copper(II) complexes and ligand precursors. Each point represents a mean value and standard deviation of 3 experiments with 3 replicates per dose.

\section{CONCLUSION}

The complexes of copper(II) with S-alkenyl derivatives of thiosalicylic acid (alkenyl = propenyl-(L1), isobutenyl(L2)) have been synthesized and characterized by microanalysis, infrared spectroscopy, and magnetic measurements. The cytotoxic effect of the copper(II)-complex was higher compared to the cytotoxicity of the corresponding ligands. Copper(II)-complexes showed slightly lower cytotoxicity compared to cisplatin. Complexes with S-alkenyl derivatives of thiosalicylic acid in concentrations from 250 to $1000 \mu \mathrm{M}$ had a cytotoxic effect on HCT-116 cells that was similar to cisplatin.

\section{Acknowledgement}

This work was financially supported by the Ministry of Education, Science and Technological Development of the Republic of Serbia (Projects 172016, 172034, 175069 and 175103), and Faculty of Medical Sciences for grant MP 2014/01.

\section{REFERENCES}

1. Tisato F, Marzano C, Porchia M, Pellei M, Santini C. Copper in diseases and treatments, and copper-based anticancer strategies. Med Res Rev. 2010;30(4):708-49.

2. Marzano C, Pellei M, Tisato F, Santini C. Copper Complexes as Anticancer Agents. Anticancer Agents Med Chem. 2009;9:185-211.

3. Prudhomme M. Advances in Anticancer Agents in Medicinal Chemistry. Clermont-Ferrand: Bentham Science Publishers; 2013(2).

4. Santini C, Pellei M, Gandin V, Porchia M, Tisato F, Marzano C. Advances in copper complexes as anticancer agents. Chem Rev. 2014;114(1):815-62.
5. Marcel, Gielen, Tiekink, Edward. Metallotherapeutic drugs and metal-based diagnostic agents. Chichester: John Wiley \& Sons Ltd; 2005.

6. Goodman VL, Brewer GJ, Merajver SD. Copper deficiency as an anti-cancer strategy. Endocr Relat Cancer. 2004;11(2):255-63.

7. Rae TD, Schmidt PJ, Pufahl RA, Culotta VC, O'Halloran TV. Undetectable intracellular free copper: The requirement of a copper chaperone for superoxide dismutase. Science. 1999;284:805-8.

8. Daniel KG, Harbach RH, Guida WC, Dou QP. Copper storage diseases: Menkes, Wilson's, and cancer. Front Biosci. 2004;9:2652-62.

9. Molina-Holgado F, Hider RC, Gaeta A, Williams R, Francis P. Metals ions and neurodegeneration. Biometals. 2007;20:639-54.

10. Iakovidis I, Delimaris I, Piperakis SM. Copper and its complexes in medicine: a biochemical approach. Mol Biol Int. 2011;2011:594529.

11. Aust SD, Morehouse LA, Thomas CE. Role of metals in oxygen radical reactions. J Free Radic Biol Med. 1985;1:3-25.

12. Daniel KG, Gupta P, Harbach RH, Guida WC, Dou QP. Organic copper complexes as a new class of proteasome inhibitors and apoptosis inducers in human cancer cells. Biochem Pharmacol. 2004;67:1139-51.

13. Chhakkar Ak, Kakkar LR. Extractive-spectrophotometric method for the determination of palladium using thiosalicylic acid and hexylamine. Fresenius J Anal Chem. 1993;347(12):483-5.

14. Gregory GREC and Jeffery PG. Salicylideneamino-2-thiophenol a new reagent for the photometric determination of tin: application to the analysis of ores, rocks and minerals. Analyst. 1967;92:293-9.

15. Gismera MJ, Procopio JR, Sevilla MT, Hernandez L. Copper(II) ion-selective electrodes based on dithiosalicylic and thiosalicylic acids. Electroanalysis. 2003;15(2):126-32.

16. Aydin M, Arsu N, Yagci Y. One-component biomolecular photoinitiating systems. Macromol Rapid Commun. 2003;24:718-23.

17. Shander D, Ahluwalia G, Grosso D. Us Patent 5411991.

18. Tarbet B. Skin disorders, therapy using fungicides. U.S. Patent Application No. 10/706,708.

19. Jacobelli H. US Patent 20050267095.

20. Halaschek-Wiener J, Kloog Y, Wacheck V, Jansen B. Farnesyl thiosalicylic acid chemosensitizes human melanoma in vivo. J Invest Dermatol. 2003;120(1):109-15.

21. O'Halloran TV. Transition metals in control of gene expression. Science. 1993;261(5122):715-25.

22. Ferrer EG, Williams PAM. Synthesis and characterization of dimeric complex of $\mathrm{Cu}(\mathrm{II})$ with thiosalicylic acid and pyridine. Polyhedron. 1997;16(19):3323-5.

23. Bott RC, Healy PC, Sagatysb DS. Electrochemical synthesis and structural characterization of the trinuclear copper(I)-copper(II) complex: bis[bis(triphenylphosphine)copper(I)][bis(thiosalicylate)copper(II)]. Chem Commun. 1998;2403-4. 
24. Nikolić MV, Mijajlović MŽ, Jevtić VV, Ratković ZR, Radojević ID, Čomić LjR et al. Synthesis, characterization and antimicrobial activity of copper(II)-complexes with some S-alkyl derivatives of thiosalicylic acid. Crystal structure of the binuclear copper(II)-complex with S-methyl derivatives of thiosalicylic acid. Polyhedron. 2014;79:80-7.

25. Nikolić MV, Mijajlović MŽ, Jevtić VV, Ratković ZR, Novaković SB, Bogdanović GA et al. Cytotoxicity of copper(II)-complexes with some S-alkyl derivatives of thiosalicylic acid. Crystal structure of the binuclear copper(II)-complex with S-ethyl derivatives of thiosalicylic acid. Journal of Molecular Structure. 2016;1116:264-71.

26. Radić GP, Glođović VV, Radojević ID, Stefanović OD, Čomić LjR, Ratković ZR et al. Synthesis, characterization and antimicrobial activity of palladium(II) complex with same alkyl derivates of thiosalicylic acids: Crystal structure of the bis(S-benzyl-thiosalicylate)--palladium(II)-complex, [Pd(S-bz-thiosal $\left.)_{2}\right]$. Polyhedron. 2012;31(1):69-76.

27. Mosmann T. Rapid colorimetric assay for cellular growth and survival: application to proliferation and cytotoxicity assays. J Immunol Methods. 1983;65:55-63.

28. Schoenberg LN, Cooke DW, Liu CF. Nuclear magnetic resonance determination of the absolute configuration of complexes of cobalt(III) with asymmetric tetradentate ligands. Inorg Chem. 1968;7:2386-93.

29. Swaminathan K, Busch DH. The synthesis and infrared absorption spectra of complexes of cobalt with pentadentate propylenediaminetetraacetic acid. J Inorg Nucl Chem. 1961;20(1):159-63.

30. Nakamoto K. Infrared spectra of the inorganic and coordination compounds. New York: Willey; 1963.

31. Ferrer, EG, PAM Williams. Synthesis and characterization of a dimeric complex of $\mathrm{Cu}(\mathrm{II})$ with thiosalicylic acid and pyridine. Polyhedron. 1997;16(19):3323-5.

32. Elmali A. The magnetic super-exchange coupling in copper(II) acetate monohydrate and a redetermination of the crystal structure. Turkish Journal of Physics. 2000;24:667-72.

33. Jotham RW, Kettle SFA, Marks JA. Antiferromagnetism in transition-metal complexes. Part VI. Low-lying excited states of dinuclear copper(II) complexes with bridging multidentate Schiff's base groups and some related compounds. J Chem Soc, Dalton Trans. 1974;2:125-8.

34. Meier JL, Coughenour CE, Carlisle JA, Carlisle GO. The magnetic properties of a series of copper(II) aspirinates. Inorg Chim Acta. 1985;106:159-63.

35. Underhill AE, Bougourd SA, Flugge ML, Gale SE, Gomm PS. Metal complexes of anti- -inflammatory drugs. Part VIII: Suprofen complex of copper(II). J Inorg Biochem. 1993; 144:139-44. 